\title{
A Design of Centrifugal Pumps With 250 Liters / Second Capacity for Water Supply at Boarding School in Cibubur, Jakarta Timur
}

\author{
Sugeng Prayitno, Bambang Sudjasta, M. Rusdy Hatuwe \\ Department of Mechanical Engineering, Faculty of Engineering, Universitas Pembangunan Nasional Veteran Jakarta, Indonesia
}

\begin{abstract}
This research was motivated by the existence of environmental pollution problems caused by manufacturing activities that use styrene plastic materials as part of the packaging for electronic products. To solve these problems, innovative uses of environmentally-friendly materials from natural resources are necessary. The substitution of natural materials for the synthetic materials used in manufacturing is vitally important in the effort to eliminate the negative effects of environmental pollution. The use of trial-and-error methods to create and test replacement materials derived from renewable natural resources will allow sustainable manufacturing development. In this study, we assessed the feasibility of replacing styrene plastic materials, which commonly are used in the packaging of manufactured goods, with waste materials from banana stems so that the packaging of manufactured goods can be an environmentally-friendly product. The resulting banana stem of new and renewable material substitution for sustainable manufacturing, namely the $\mathrm{M}_{4}+\mathrm{T}+\mathrm{P}_{3}+\mathrm{A}+\mathrm{t}_{6}$ model. Micro-biological banana stem material is broken down easily in the soil, so this material does not disturb the environment, while styrene materials do not break down in the soil. The implication of this research is the packaging of manufactured products can be sustainable.
\end{abstract}

Keywords : Sustainable Manufacture, Centrifugal pump, Water supply

\section{Introduction}

The need for clean water is very important for the basic needs of living things, especially humans. Humans use clean water for various purposes in everyday life. In the environment of a cottage, clean water will affect various aspects including the health of the community, including economic, social, as well as improvements in urban / rural life and the environment itself. A pump planning has many things that need to be considered in its planning which includes the type of pump to be used, the piping line, the pipe material used, the calculation of the pipe diameter, the total head of the pump, and the losses that will occur.

A pump is a device used to move a liquid (fluid) from one place to another, through a medium by giving energy to the fluid being transferred, converting the mechanical energy into kinetic energy. The mechanical energy provided by the pump is used to increase speed, pressure, or elevation (altitude).

In general, the pump is driven by a motor, machine or the like. Many factors cause the type and size of the pump and the material for which it is made different, among others, it is influenced by the type of fluid and the volume of the fluid, the height and distance of the fluid transport, as well as the pressure required and so on. The working principle of the pump itself makes the difference in pressure between the suction parts. and the press (discharge).

In a place or cottage / water production, there is always a situation where the treated materials are moved from one place to another or one place of storage to another place.

processing. This transfer can also be intended to carry the material to be processed from the source where the material is obtained. The higher liquid will flow itself to a lower place, but if it is the other way around it requires effort to move or raise the fluid, then the commonly used tool is a pump.

Fluid Mechanics is a branch of mechanical engineering that studies the balance and movement of gases and liquids as well as the forces of attraction to the objects around them or those that are passed while flowing. In the industrial world, most of the fluid flows in a closed pipe (close conduit flow).

Water Treatment Plant (WTP) is a system or facility that functions for treat water of the desired water quality according to quality standards or ready for consumption. Water Treatment Plant is an important facility around the world to produce clean and healthy water for consumption. [2]

In this cottage environment, a clean water supply that is in accordance with the quality standards of clean water that can be used for the needs of the students and drinking water will be needed, a WTP facility will be 
built, whose water source will be taken through a reaping well, a maximum capacity of 250 liters / second (250 lps). in accordance with the SIPA (Water Extraction Permit) that has been set by the local government for the environmental area

\section{Reserach Methods}

This research was conducted in the Cibubur area of East Jakarta, which is about to be built, with a total environmental area of 5 ha. The water source that will be used for this area uses the WTP facility which will be prepared by the developer / third party. The water supply source itself will be taken from several infiltration wells with a permissible water intake capacity of 250 liters / second according to the issued / obtained SIPA. This water source itself will be flowed through an intake which will also be prepared by a third-party developer to the cottage environment by using a pump that will flow water to the WTP with a distance of $+100 \mathrm{~m}$ from the intake.

This study will design a centrifugal pump with a capacity of 250 liters / second using the French method (Analysis), before conducting the analysis there are steps that must be done, namely the data collection stage in the form of field data and literature data related to the design that is collected and processed by grouping it. based on each category. The processed data will be used as material for analysis in the planning.

The results of the analysis function to determine the problems and advantages that exist in similar buildings and their suitability with literature data so as to produce a good plan.

This planning uses a design methodology such as a flowchart as follows:

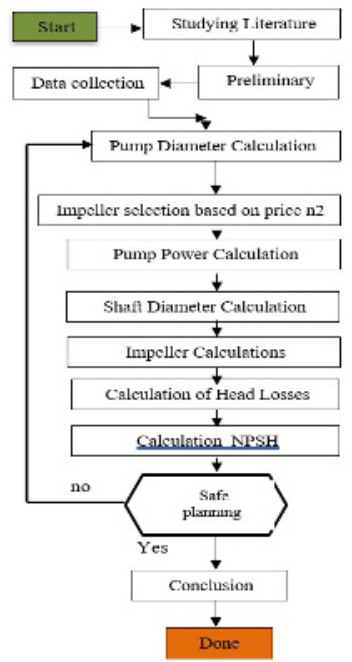

Fig.1. Research Flowchart

\section{Result and Discussion}

The design of a centrifugal pump for WTP with a capacity of 250 liters / second for the Pondok environment will flow raw clean water from infiltration wells to the WTP to the Pondok Environment with the following data :

1. Capacity $(\mathrm{Q})=250$ liters $/ \mathrm{second}=0.25$ $\mathrm{m}^{3} / \mathrm{S}$.

2. Pipes to be used use Galvanized pipe material and for distribution pipes to the WTP using HDPE pipes.

3. The fluid used is clean water from a well

4. Viscosity $=0.800 \times 10-6 \mathrm{~m} 2 / \mathrm{s}$

5. $\mathrm{Sp} \mathrm{Gr}=1000 \mathrm{~kg} / \mathrm{m} 3$

6. Velocity $=1.5 \mathrm{~m} / \mathrm{s}(0.8-1.5 \mathrm{~m} / \mathrm{s})$

7. $\mathrm{Head}=90 \mathrm{~m}$

The following is a picture of the pipeline from the intake to the WTP :

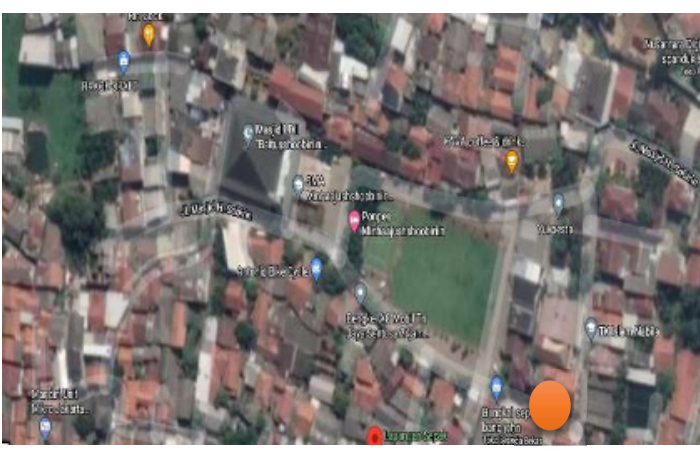

Fig.2. Map of the intake route

\subsection{Pipe diameter calculation}

From the data obtained, it can be calculated the pipe diameter using the formula :

$$
\begin{aligned}
& Q=v \cdot A \\
& A=Q / v
\end{aligned}
$$

Dimana :

$$
\begin{aligned}
& \mathrm{Q}=\text { Water discharge } \\
& \mathrm{A}=\text { Cross-sectional area } \\
& \mathrm{v}=\text { Flow velocity }
\end{aligned}
$$

- pipe diameter required is :

$$
\begin{aligned}
& Q=v \cdot A \\
& A=Q / v \\
& A=0,25 / 1,5=0,167 m^{2} \\
& A=\left(\left(\pi x d^{2}\right) / 4\right. \\
& d^{2}=(A x 4) / 3,14 \\
& d^{2}=(0,167 x 4) / 3,14 \\
& d=0,461 m
\end{aligned}
$$

From these calculations, the diameter is $0.461 \mathrm{~m}$, then the pipe size is selected according to the galvanic 
pipe catalog on the market, so a pipe with a diameter of 20 inches with sch 40 and a wall thickness of 15.0622 $\mathrm{mm}$ is selected.

\subsection{Reynolds number}

$$
\mathrm{Re}=\frac{\mathrm{v} \cdot d}{v}
$$

From these calculations, the Reynolds value obtained is more than 4000 , it can be concluded that the water flow in the pipe is turbulent.

\subsection{Pump Impeller Design}

The specific velocity (ns) can be used as a parameter for determine the type of pump impeller according to the following figure :

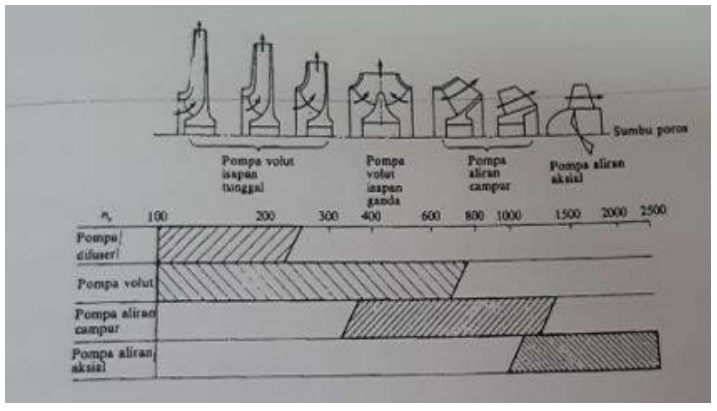

Fig.3. Types of Impeller according to their specific speed

Based on the figure, there are 4 types of impellers based on their specific rotation, namely :

$\mathrm{ns}=(100-250)=$ Radial type impeller

$\mathrm{ns}=(100-780)=$ French impeller

$\mathrm{ns}=(320-1400)=$ Mixed flow type impeller

$\mathrm{ns}=(890-2500)=$ Axial type impeller

$$
n_{s}=n \cdot \frac{O^{0,5}}{H^{0,75}}
$$

Where :

$$
\begin{array}{ll}
n_{S} & =\text { Specific loop } \\
\mathrm{Q} & =\text { Specific capacity }(\mathrm{m} / \mathrm{s}) \\
\mathrm{H} & =\text { Pump head }(\mathrm{m}) \\
\mathrm{n} & =\text { Pump speed }(\mathrm{rpm})
\end{array}
$$

In this planning obtained :

From the specific rotation obtained, the impeller shape can be determined by looking at the following classification : ns $=(12-35)=$ Radial type impeller

$\mathrm{ns}=(36-80)=$ French impeller

$\mathrm{ns}=(80-160)=$ Mixed flow type impeller

$\mathrm{ns}=(161-400)=$ Axial type impeller

Based on the calculation of the specific rotation above, the pump used or planned is the French type because the specific rotation of the pump is $41.73 \mathrm{rpm}$.

\subsection{Calculation of Head Losses}

\subsubsection{Head loss on straight pipe}

From previous calculations, it is known that the flow in the pipe is turbulent with a value of 862500 and the Hazen-Wiliam coefficient $(\mathrm{C})$ for galvanized iron pipe is 120 [6], so to find the head loss it can be found with the formula :

- For straight pipe losses on the suction side of the pump, namely:

- As for the straight side of the pump, namely:

- So that the total losses in straight pipes:

a. Looking for losses in pipe accessories After calculating the value of losses (resistance) at straight pipe, so now we calculate the resistance value of pipe accessories such as: Elbow, butterfly valve, tee, check valve, etc.

Table 1. Types of valves and their friction

\begin{tabular}{|l|l|l|l|l|l|l|l|l|}
\hline & \multicolumn{7}{|c|}{ Valve Diameter (mm) } \\
\hline Valve Tipe & 100 & 150 & 200 & 250 & 300 & 400 & 500 \\
\hline slide valve & 0,14 & 0,12 & 0,10 & 0,09 & 0,07 & 0 & 0 \\
\hline $\begin{array}{l}\text { Butterfly } \\
\text { Valve }\end{array}$ & \multicolumn{7}{|c|}{$0,6-0,16$} \\
\hline rotary valve & \multicolumn{7}{|c|}{$0,09-0,026$} & \\
\hline $\begin{array}{l}\text { Swing type } \\
\text { Prevent } \\
\text { Valve }\end{array}$ & & & 1,2 & 1,15 & 1,1 & 1,0 & 0,98 \\
\hline $\begin{array}{l}\text { Pressure } \\
\text { type } \\
\text { closing } \\
\text { prevent } \\
\text { valve }\end{array}$ & & & 1,2 & 1,15 & 1,1 & 0,9 & 0,8 \\
\hline $\begin{array}{l}\text { Free lift } \\
\text { type } \\
\text { prevent } \\
\text { valve }\end{array}$ & 1,44 & 1,39 & 1,34 & 1,3 & 1,2 & & \\
\hline $\begin{array}{l}\text { Spring type } \\
\text { quick close } \\
\text { prevent } \\
\text { valve }\end{array}$ & 7,3 & 6,6 & 5,9 & 5,3 & 4,6 & & \\
\hline $\begin{array}{l}\text { Suction } \\
\text { valve with } \\
\text { filter }\end{array}$ & 1,97 & 1,91 & 1,84 & 1,78 & 1,72 & & \\
\hline
\end{tabular}


b. Disadvantages of the suction equipment:

The tee connection on the suction section is 2 pieces, from the table we can know the equivalent length is $80 \mathrm{D}$, so that:

Then calculate the losses on the suction valve and filter using the equation :

$$
h_{f}=f \frac{v^{2}}{2 g}
$$

The $f$ value is obtained from the table, with the $\mathrm{f}$ value for the butterfly valve, which is 0.6 for the diameter $400 \mathrm{~mm}$, so that :

$$
h_{f}=0,6 \frac{(1,5 \mathrm{~m} / \mathrm{s})^{2}}{2 \times 9,81 \mathrm{~m} / \mathrm{s}^{2}}=0,068 \mathrm{~m}
$$

Thus, the total loss of accessories on the suction side is equal to

$$
h_{f}=\left(8,39 \times 10^{-3}\right)+0,068=0,076 \mathrm{~m}
$$

c. Losses on the accessories on the press side: The number of elbows 900 on the press side pipe is 10 pieces so that:

$$
\begin{aligned}
h_{f} & =10 \times \frac{10,666\left(0,25 \mathrm{~m}^{3} / \mathrm{s}\right)^{1,85}}{\left(120^{1,85}\right)\left(0,4869^{0,85}\right)} \times(32 \times 0,4869 \mathrm{~m}) \\
& =0,033 \mathrm{~m}
\end{aligned}
$$

The number of tee joints on the press section is 5 pieces, from the table the equivalent length is $80 \mathrm{D}$, so that :

$$
\begin{aligned}
h_{f} & =5 \mathrm{x} \frac{10,666\left(0,25 \mathrm{~m}^{3} / \mathrm{s}\right)^{1,85}}{\left(120^{1,85}\right)\left(0,4869^{0,85}\right)} \times(80 \mathrm{x} 0,4869 \mathrm{~m}) \\
& =0,041 \mathrm{~m}
\end{aligned}
$$

In the press section there are 5 check valves and 5 butterfly valves where :

The value of $\mathrm{f}$ is taken the highest value from the table of 0.6 so that :

$$
h_{f}=10 \times 0,6 \frac{(1,5 \mathrm{~m} / \mathrm{s})^{2}}{2 \times 9,81 \mathrm{~m} / \mathrm{s}^{2}}=0,68 \mathrm{~m}
$$

So that the total losses on the compressive side are:

$h_{f}=0,033+0,041+0,68=0,754 \mathrm{~m}$

So that the total loos of accessories on the piping is:

$h f=0,076+0,754=0,83 \mathrm{~m}$

\subsection{Total Head loss}

Total losses in pipeline installation are the sum of losses on straight pipes and on pipe accessories. In this design there is a piece of equipment in the form of a filter assume an allowable pressure loss of 0.5 bar for one unit, so that:

$$
\begin{aligned}
& h_{f \text { total }}= h_{f \text { pipa lurus }}+{ }^{h} f \text { aksesories }+ \\
& h_{f \text { equipment }} \\
& h_{f \text { total }}=1,07+0,83+5=6,9 \mathrm{~m} .
\end{aligned}
$$

\subsection{Looking for NPSH}

NPSH (Net Positive Suction Head) is the head that the liquid has on the suction side of the pump or the absolute pressure on the suction side of the pump minus the saturated vapor pressure of the liquid in that place. Where the existing parameters for performing calculations are as follows :

- The working temperature of the pump in the pump area is $300 \mathrm{C}(\mathrm{Pv})$

The saturated vapor pressure obtained the Value of $\mathrm{Pv}=0.04325 \mathrm{kgf} / \mathrm{cm} 2=238.3 \mathrm{kgf}$ $/ \mathrm{m} 2$

- Atmospheric pressure in the work Environment $(\mathrm{Pa})$ Atmospheric pressure with an altitude of $0-100 \mathrm{~m}$ above sea level, Which is $10.33 \mathrm{~m} \mathrm{H} 2 \mathrm{O}=1.033 \mathrm{kgf} / \mathrm{cm}^{2}=$ $10330 \mathrm{~kg} / \mathrm{m}^{2}$

- Specific gravity (y) of the working fluid is $995.7 \mathrm{kgf} / \mathrm{m} 2$

- Head loss on the suction side. hf suction side $=\mathrm{hf}$ straight pipe on suction side $+\mathrm{hf}$ suction side accessories hf suction side $=1.29 \times 10^{-3}$ $+0.076=0.07729 \mathrm{~m}$

- Static head on the suction side hs suction side $=8 \mathrm{~m}$ so that the NPSH calculation available on the system is:

$$
\begin{aligned}
H_{S v} & =\frac{P_{a}}{y}-\frac{P_{v}}{y}-h_{s}-h_{f} \\
H_{S v} & =\frac{10330 \mathrm{kgf} / \mathrm{m}^{2}}{995,7 \mathrm{kgf} / \mathrm{m}^{3}}-\frac{238,3 \mathrm{kgf} / \mathrm{m}^{2}}{995,7 \mathrm{kgf} / \mathrm{m}^{3}}-8-0,07729 \\
H_{S V} & =10,37-0,24-8-0,07729=2,05 \mathrm{~m} \\
& =20,11 \mathrm{~J} / \mathrm{kg}
\end{aligned}
$$

\section{Conclusion}

From the descriptions and calculations in the previous chapters, for the planning of a centrifugal pump with a capacity of 250 liters / second in the Pondok Cibubur 
East Jakarta environment, the authors draw the following conclusions:

1. The planned pump has:

a. Capacity (Q): $0.25 \mathrm{~m} 3 / \mathrm{s}$

b. Head: $90 \mathrm{~m}$

c. Rotation: $1450 \mathrm{rpm}, 50 \mathrm{~Hz}, 4$ poles

d. Shaft Power: $245.25 \mathrm{~kW}$

e. Number of blades: 9 blades

f. Temperature: $30^{\circ}$

1. This pump has a radial type impeller using a pump level 2 and specific speed (Ns): $41.73 \mathrm{rpm}$.

2. For the value of Head losses in straight pipe 1.071 $\mathrm{m}$

3. The value of Head losses in piping accessories is $0.83 \mathrm{~m}$.

4. For the total head losses, $6.9 \mathrm{~m}$

5. For NPSH of $20.11 \mathrm{~J} / \mathrm{kg}$.

Based on the pump capacity at point 0 , the pump head is at the highest value, when the capacity is greater, the head will decrease and the power will quickly increase, and if the capacity is increasing or exceeding the standard capacity, the efficiency is at the highest point and will decrease.

\section{References}

1. Sebayang, P., Muljadi Tetuko, A.P., Kurniawan, C. Sari, A.Y. Nurdiyansah, L.F., 2015, "Teknologi Pengolahan Air Kotor dan Payau Menjadi Air Bersih dan Layak Minum", Jakarta: LIPI press.

2. Standar Nasional Indonesia (SNI)6774: 2008 tentang Tata cara perencanaan unit paket instalasi pengolahan air, Badan Standarisasi Nasional.

3. Melati wahyu rizki pratami. "Perencanaan Sistem Pengolahan Lumpur IPA Pejompongan I \& II Jakarta", Skripsi Tugas Akhir Teknk Lingkungan Universitas Indonesia, Depok Juni 201

4. Selintung Mary." Perencanaan bangunan Pengolahan air minum”, Jurusan Teknik Lingkungan Universitas Hasanudin

5. MohIryandhasyah Akbar, "Analisis dan pengujian pompa sentrifugal sebagai studi awal perancangan pump storage plant" Jurusan Teknik Mesin, Fakultas Teknik, Universitas Pancasila, J a karta Indonesia.

6. Wibowo Paryatmo, 2005. “ POMPA”. Universitas Pancasila Jakarta Indonesia.

7. Sularso, Tahara Haruo. 1987. "Pompa dan Kompressor: Pemilihan Pemakaian, dan Pemeliharaan". Jakarta: PT. Pradnya Paramita. 